European Journal of Business and Innovation Research

Vol.8, No.5, pp 38-55, August 2020

Published by $\boldsymbol{E C R T D}-\boldsymbol{U K}$

Print ISSN: 2053-4019(Print), Online ISSN: 2053-4027(Online)

\title{
ANALYSIS OF FINANCIAL PERFORMANCE OF PDAMS AFFECTED BY ENVIRONMENTAL PERFORMANCE AND ENVIRONMENTAL ACCOUNTING WITH AGENCY COST MEDIATION
}

\author{
Hendra Setiawan, \\ Student Doctoral Program Faculty of Economics and Business, Universitas Trisakti, \\ Lecturer in Accounting Departement, Faculty of Bussenes IBIK, Indonesia \\ Sekar Mayangsari, \\ Faculty of Economics and Business, Universitas Trisakti, Indonesia
}

\begin{abstract}
Financial Performance is a benchmark for a company in assessing the success and sustainable companies of each age. At this time, the environment is very influential on the performance of the company's finances. This study will analyze the financial performance of PDAM Indonesia which is influenced by environmental performance and environmental accounting by mediating agency costs. This study only used a sample of 37 PDAMs that met established criteria with the type of research being used as explanatory research. The research method used is multiple linear regression with data analysis using SPSS software. The test results show that the financial performance of PDAMs is negatively affected directly by environmental performance and is insignificant while environmental accounting in contrast has a positive effect. Meanwhile, environmental performance is mediated by agency costs so that it does not directly affect the positive effect on PDAM's financial performance as well as environmental accounting. PDAMs that provide high agency costs to the PDAM board of directors increase PDAM financial performance.
\end{abstract}

Keywords: performance and environmental accounting, financial performance, agency cost JEL Classification: L25, L32, M41

\section{INTRODUCTION}

For a company to be sustainable in its business world, the company must have good financial performance. A company that has good financial performance can develop its business so that the company can still exist in the business world. This is in line with one of the management systems of a company called the balance scorecard (Crowther \& Aras, 2008; Nazarian, Atkinson, \& Foroudi, 2017). Balanced scorecard is a way that evaluates factors that affect company performance consisting of perspectives (1) innovation and learning - companies continue to create and enhance company value (2) internal business - the company shows excellence (3) customer perspective - the company analyzes customer satisfaction (4) financial perspective - how companies view financial conditions (Crowther \& Aras, 2008). Almost all industries must pay attention to their finances as in Wang's research (2016) where companies must pay attention to corporate social performance (CSP) on financial performance (H. Wang, $\mathrm{Lu}$, Ye, Chau, \& Zhang, 2016), the insurance industry in the UK that pays attention to reinsurance of financial performance (Shiu, 2019), the hospital industry that pays attention to corporate social responsibility (CSR) and the quality management of financial performance 
European Journal of Business and Innovation Research

Vol.8, No.5, pp 38-55, August 2020

Published by ECRTD-UK

Print ISSN: 2053-4019(Print), Online ISSN: 2053-4027(Online)

(Franco, Caroli, Cappa, \& Del Chiappa, 2019), the tourism industry that pays attention to CSR towards financial performance (Theodoulidis, Diaz, Crotto, \& Rancati, 2017), the energy industry in Brazil that pays attention to financial ratios and clusters to financial performance (Rodrigues \& Rodrigues, 2018), the Brazilian textile industry which pays attention to environmental performance on financial (Lucato, Costa, \& de Oliveira Neto, 2017), industry banks that pay attention to corporate social performance on financial (Esteban-Sanchez, de la Cuesta-Gonzalez, \& Paredes-Gazquez, 2017), the transportation industry that pays attention to corporate political activity (CPA) to financial performance (Brown, 2016), and restaurants that pay attention to CSR to financial performance (Rhou, Singal, \& Koh, 2016). Based on this, all industries always pay attention to financial performance associated with various factors that influence it.

Financial performance research results indicate factors related to financial performance including CSR (Franco et al., 2019; Jahmane \& Gaies, 2020; Rhou et al., 2016; Theodoulidis et al., 2017), CSP (Esteban-Sanchez et al., 2017; H. Wang et al., 2016), environment (Liu, 2020; Lucato et al., 2017; Petitjean, 2019; Tzouvanas, Kizys, Chatziantoniou, \& Sagitova, 2019), digital business strategies (Ukko, Nasiri, Saunila, \& Rantala, 2019), organizational and stakeholder regulation (Baah, Jin, \& Tang, 2020), networking and innovation (Etriya, Scholten, Wubben, \& Omta, 2019), agency cost (Gan, Park, \& Suh, 2020), corporate governance (Alahdal, Alsamhi, Tabash, \& Farhan, 2020), energy efficiency (Moon \& Min, 2020), family involvement (Hansen \& Block, 2020), and the disclosure of information contributions (S. Wang, Wang, Wang, \& Yang, 2020). Based on previous research relating to financial performance, factors related to financial performance and still interesting to study are the environment and agency costs.

In this age, environmental pollution is very concerned. Companies in carrying out their activities must pay attention to the environment. Therefore, the company must manage the environment around the company which is a strategic step for the company to be able to survive and interact with stakeholders (Haholongan, 2016; Tahu, 2019). Two things done by companies related to the environment are performance (Chege \& Wang, 2019; Martinez, Alvarez, Capuano, \& Delgado, 2020; Singh, Giudice, Chierici, \& Graziano, 2020) and accounting (Qian, Hörisch, \& Schaltegger, 2018; Usman, Alola, \& Sarkodie, 2020) enviroment. The company carries out environmental management (environmental performance) for the survival of the company (Chege \& Wang, 2019) while companies still have to take into account the costs of environmental management (environmental accounting) (Qodriana, 2017; Ratulangi, Pangemanan, \& Tirayoh, 2018). Companies that carry out environmental performance will increase their production capacity (Josephine \& Harjanti, 2017), influence the quality of drinking water (Kurniawan, 2019), and provide financial success (Chege \& Wang, 2019). Environmental accounting by companies can inform companies of the financial use of the environment in detail (Usman et al., 2020; M. X. Wang et al., 2019), competitive advantage, revenue (Utama, 2016), and better company management (Qian et al., 2018). Therefore, companies must care about the environment.

In environmental management, there are company owners who appoint a manager (agency) (Adib, 2016). It is intended that the company generates a maximum return on investment (Adib, 2016). Therefore, the company owner must pay a fee to pay the manager who manages the 
European Journal of Business and Innovation Research

Vol.8, No.5, pp 38-55, August 2020

Published by $\boldsymbol{E C R T D}-\boldsymbol{U K}$

Print ISSN: 2053-4019(Print), Online ISSN: 2053-4027(Online)

company called agency cost (biaya agensi) (Adib, 2016). Agency costs are costs incurred by the company owner to the manager where the amount of these costs must be reasonable. These costs affect the asset utilization ratio and have an impact on company performance (Layyinaturrobaniyah, Sudarsono, \& Fitriyana, 2014), financial performance (Muchlas \& Alamsyah, 2017; Varela, 2017), and service quality (Canitez, Alpkokin, \& Black, 2019). Therefore, the cost of a company owner to pay managers influences the company's financial performance.

Regional water company (PDAM) is a regional company in Indonesia that provides clean water for the needs of the people in an area. Therefore, the environment is one indicator that influences the performance of PDAMs. PDAM is a regional company that guarantees the basic water needs for the community by meeting the quality, quantity and continuity requirements of the drinking water. This was stated in the Law on Water Resources (7 of 2004) and local governments (32 of 2004) (Indonesia, 2004b, 2004a). Based on this, the PDAM must carry out environmental management and accounting so that the drinking water is suitable for consumption (Suseno \& Widyastuti, 2014). Matters affecting the performance of PDAMs include service quality (R \& Hafifi, 2017; Sianipar \& Wahyono, 2018; Sumantri \& Parwiyanto, 2017), human resource performance (Istiana, 2017), financial performance, operations, administration (Prakoso, Jonathan, \& Lau, 2013), and the quality of drinking water produced (Suseno \& Widyastuti, 2014). Based on this, the performance factors that need to be considered by PDAM are financial performance and water quality.

The impact of environmental concern undertaken by the PDAM on its financial performance will be analyzed in this study. Environmental care by the PDAM is seen from the aspect of performance and environmental accounting. In addition, agency cost is also used as one of the variables that will be analyzed for its impact on the relationship between the PDAM's concern for the environment and its financial performance. The control variables of this study are size, service coverage, non-revenue water (NRW), and employee ratio. PDAMs in Indonesia are used as research populations. Data processing uses statistical package software for the social sciences (SPSS). Environmental performance, environmental accounting and agency costs that have been tested will be analyzed for their effect on the financial performance of the PDAM. The PDAM can use the results of this research in managing the environment without reducing its financial performance.

\section{LITERATURE REVIEW}

\section{Theory}

Denton (1994) states that enviromanagement is a way of looking at a company that sees that the environment is not a cost for the company but an asset for the company (Destia, 2013; Fitria \& Wibowo, 2015). According to El-Kholy (2001: 15), enviromanagement or environmental management is a process related to human-environmental interaction, and seeks to identify: what the environment wants; what are the physical, economic, social and technological obstacles to achieving it; and what are the most viable choices (Barrow, 2006). One important element in enviromanagement is the paradigm or perspective (Fitria \& Wibowo, 2015). This perspective is based on two aspects, namely the perspective of companies and consumers. Companies that view the environment as a cost, the company will always avoid, but if you 
view it as an investment strategy of the company, the environment will be managed well (Fitria $\&$ Wibowo, 2015). Consumers see if the company carries out its responsibility to the environment, then the products made will be accepted by consumers but if not, then the company's products will be rejected by consumers (Destia, 2013). The science of enviromanagement is developing very rapidly. This science is very important because many sectors of human activity play an important role in sustainable development. All sectors such as government, business, society become more involved in environmental issues and the mass media covers it quickly so that information distortion can be hidden by polarized perceptions so that environmental-related policies are not well received by these sectors (Barrow, 2006). Enviromanagement filters all this information by displaying and differentiating accurate and inaccurate data to avoid misinformation of the actual causes, giving advice and educating stakeholders to find the best environmental management options (Barrow, 2006).

Donaldson and Davis (1991) state that a strong relationship between organizational satisfaction and success is stewardship theory. Organizational success results from optimal and optimal management and shareholder activities. According to Haliah (2015), this activity maximizes the interests of individuals in the group of the organization to advance the company (Jefri, 2018). Hernandez (2008) states that the attitudes and behaviors of corporate actors on the theory of stewardship place organizational interests above personal interests in the long run (Jefri, 2018). The company actor has a high responsibility for the impact of all his actions on the welfare of stakeholders (Madison, 2014). According to Davis et. all. (1997), a steward maintains and maximizes shareholder wealth through company performance (Jefri, 2018; Madison, 2014). Based on Stewardship theory, management is the backbone of the company's success in achieving company goals so that the welfare of shareholders increases. Efficient and efficient organizational performance will provide shareholder and management satisfaction.

In addition to stewardship theory, the relationship between company owners and managers is discussed in agency theory (Aprianingsih, 2016; Kovermann \& Velte, 2019; Sofia, 2019; Varela, 2017). In agency theory, agency relationship arises when the company owner employs and delegates his authority to someone (agent) in managing the company (Aprianingsih, 2016). However, sometimes problems arise where conflicts occur where there are differences of opinion and information between company owners and managers (Kovermann \& Velte, 2019). Therefore, the agent or manager has the obligation to inform the owner of the company's real condition and performance. To monitor performance and have an engagement with a manager, the company owner pays and pays the manager (agency cost) (Varela, 2017). According to Jensen and Meckling (1976) there are three types of agency costs. First, the monitoring cost by the principle whereby these costs are to monitor and control agent behavior through compensation policy and budget restriction. Second, the bonding cost where this cost is to ensure that the agent will not take actions that will harm the owner of the company, such as the willingness of management to hire the services of an auditor to audit the financial statements they make. Third, the residual loss which is a decrease in the welfare level of principals and agents despite monitoring costs and bonding costs (Chamidah \& Asandimitra, 2017).

Environmental performance is a voluntary program of the company that pays attention to the environment with stakeholders viewed from the legal field (Haholongan, 2016). The results of the company's strategic activities that have an impact on the environment can also be said of 
European Journal of Business and Innovation Research

Vol.8, No.5, pp 38-55, August 2020

Published by $\boldsymbol{E C R T D}-\boldsymbol{U K}$

Print ISSN: 2053-4019(Print), Online ISSN: 2053-4027(Online)

environmental performanc (Walls, Berrone, \& Phan, 2012). In addition, Suratno et al., (2006) also stated that the performance of companies in protecting and caring for the environment for the better was the company's environmental performance (Tahu, 2019). In managing the environment, companies require large investments and in the long run so that the risk to the company's finances (Walls et al., 2012). One measure of a company's achievements in managing the environment is by following the Company Performance Rating Rating Program in Environmental Management (PROPER). PROPER is a program from the Ministry of Environment (KLH) to encourage and motivate companies in managing the environment. The company's obedience in implementing PROPER becomes the benchmark of KLH in giving intensive or not to the company and the company's reputation is announced to the public (Nurputri \& Nuzula, 2019).

In managing the environment, companies are required to pay attention to their financial management (environmental accounting) so that the company can carry out conservation and environmental management in a sustainable manner in order to improve its business results (Ratulangi et al., 2018). Makarin (2004) states that environmental management needs to be accompanied by management reporting and the cost of the production improvement system so as not to pollute the environment because it is very important (Utama, 2016). The environment is a critical and complex problem today and affects all aspects of life and economics including financial (Utama, 2016). Lutz (1991) states that there is environmental information that cannot be explained by accounting because of limitations in measuring changes and depreciation to countless environments (such as air, water, and natural gas), and the cost of repairing environmental assets (Utama, 2016). Therefore we need full awareness of the company to manage the environment by paying attention to finances and their impact for the progress of the company.

\section{Hypothesis Development}

Environmental performance is very influential on financial performance. At this time, the company must pay attention to the environment because it has a positive influence on financial performance as happened to Indonesian manufacturing companies which were in flattening in the 2009 - 2011 period (Haholongan, 2016). Companies that pay attention to the environment also have a good impact on production activities where this can increase the company's production activities that can improve the company's financial performance (Betts, Super, \& North, 2018; Martinez et al., 2020). Technology is also used in managing the environment and this has an impact on increasing company finances (Chege \& Wang, 2019). Companies that do not manage the environment have an impact on financial performance as happened in several American companies (Lu \& Taylor, 2018). From previous research, the relationship between environmental performance and corporate financial performance are:

$\mathrm{H}_{1}=$ Environmental performance positively influences financial performance.

Companies that conduct environmental management must also pay attention to the finances used to manage this. Companies that carry out activities detrimental to the environment can replace them with a variety of activities related to the environment such as the community development program (Dewata, Jauhari, Sari, \& Jumarni, 2018). The environmental management program is expected to be included in the company's financial or annual report. 
This program is expected to increase the company's reputation so that the company's turnover or profits increase (Dewata et al., 2018). The financial statements are the company's accounting which on this occasion is environmental accounting. Environmental accounting records all company finances related to the environment and this can be a competitive advantage owned by the company and cause the company's reputation to increase (Dewata et al., 2018). However, many companies have not implemented environmental accounting effectively because this company has ruled out the risk of environmental damage that occurs (Qodriana, 2017; Ratulangi et al., 2018). Environmental accounting can minimize and optimize costs incurred by the company in managing the environment (Utama, 2016) and minimize activities that are not needed for environmental management (Usman et al., 2020; M. X. Wang et al., 2019). From the previous research, the relationship between environmental accounting and financial performance is:

$\mathrm{H}_{2}=$ Environmental accounting positively influences financial performance.

Agency costs are the costs incurred by the owner to manage and supervise the performance of managers so that they work for the benefit of the company. According to Jensen and Meckling (1976), agency cost is a cost that must be incurred by a company owner to supervise agents (Chamidah \& Asandimitra, 2017). According to Fachrudin (2011), agency cost is an incentive given to managers of a reasonable magnitude and aims to oversee to avoid hazard (Adib, 2016). Based on that, company performance can be affected by agency cost. However, it has not consistently influenced company performance where agency cost can reduce or increase company performance which also affects the company's financial performance (Muchlas \& Alamsyah, 2017). Other research states that the type of company ownership in the form of family ownership can weaken agency costs thereby reducing company performance (Layyinaturrobaniyah et al., 2014). Transportation companies in Turkey that provide agency costs under government policies have an impact on the decline in performance of public transportation services (Canitez et al., 2019). Managers who work very well so that the company's financial performance increases due to high agency costs (Varela, 2017). From the previous research, the relationship between financial performance and agency cost is:

$\mathrm{H}_{3}=$ Agency cost positively influences the company's financial performance.

The company is currently required to manage the environment properly. Good environmental management must be supported by good management. This is obtained from managers who work well and creatively. Managers like that require a lot of money. Therefore companies must be willing to spend high agency costs because it can improve company performance (Varela, 2017). With high agency costs, it is likely that environmental performance can run well which has a positive impact on company performance such as companies in Kenya (Chege \& Wang, 2019), manufacturing in Indonesia (Haholongan, 2016), companies in developing countries (Betts et al., 2018), animal feed in Spain (Martinez et al., 2020), and companies in America (Lu \& Taylor, 2018). Another thing, family companies in Indonesia that do not provide high agency costs, the performance of the company is low which results in decreased financial performance (Layyinaturrobaniyah et al., 2014). This also happens to transport companies in Turkey that provide low agency costs and cause the performance of these transportation 
European Journal of Business and Innovation Research

Vol.8, No.5, pp 38-55, August 2020

Published by $\boldsymbol{E C R T D}-\boldsymbol{U K}$

Print ISSN: 2053-4019(Print), Online ISSN: 2053-4027(Online)

companies to be low (Canitez et al., 2019). From the previous research, the relationship between financial and environmental performance mediated by agency cost is:

$\mathrm{H}_{4}=$ Agency cost mediation on environmental performance positively influences financial performance.

Companies that provide high agency costs can improve company performance and corporate financial performance (Varela, 2017). This shows that agency cost can provide a positive value on company performance. Therefore, agency cost is expected to also be able to give a positive value to companies that carry out environmental accounting that have an impact on company performance (Dewata et al., 2018; Utama, 2016). In addition, agency cost is expected to provide a positive value on environmental accounting so that the management activities carried out by the company can be optimized (Usman et al., 2020; M. X. Wang et al., 2019). Companies in Indonesia that do not provide high agency costs then weaken the company's weak performance so that its financial performance decreases (Layyinaturrobaniyah et al., 2014). This also applies to transportation companies in Turkey where the company does not provide agency costs as standardized by the government so that performance decreases (Canitez et al., 2019). From the previous research, the relationship between accounting and environmental performance mediated by agency cost is:

$\mathrm{H}_{5}=$ Agency cost mediation on environmental accounting positively influences financial performance.

\section{METHODS}

The type of research used in this study is research that explains the clausal relationships between variables and tests the hypotheses that are made. According to Amerieska (2014) this test is called explanatory research (Amerieska \& Nurhidayah, 2014). This research will use regional water supply companies (PDAMs) throughout Indonesia as the population. The PDAM that was used as the research sample came from the assessment of the Agency for the Improvement of the Drinking Water Supply System (BPPSPAM) of the Ministry of Public Works and Public Housing in the healthy category. The purposive sampling method was used in sampling in this study. In addition to the healthy category, the PDAMs that become the sample are the PDAMs that supply drinking water to customers through pipelines where the water comes from raw water treatment plants or springs.

Data collection techniques used are polymer and secondary. Primary data is obtained from the results of the questionnaire given to the Directors and Heads of Section / Managers of PDAMs while secondary data is obtained from the Financial Statements and PDAM Performance in 2017 the results of financial audits by BPKP and financial audits by the Public Accountant Office (KAP) of 378 PDAMs inspected up to in 2016.

The variables in this study consisted of the dependent, independent, and mediating variables. Corporate financial performance (YKKP) is the dependent variable. The independent variable is environmental performance $(\mathrm{X} 1 \mathrm{KL})$, environmental accounting $(\mathrm{X} 2 \mathrm{AK})$ and the mediating variable is agency cost (ZAC). The company's financial performance variable (YKKP) PDAM 
is measured using profitability ratios, namely Return On Equity (ROE). According to Sugiono (2009), ROE shows the company's management of its own capital effectively, measuring the level of return on investments made by shareholders (Winarno, 2017). Therefore, ROE is calculated based on incoming net income divided by Equity. The environmental performance variable $\left(\mathrm{X}_{1} \mathrm{KL}\right)$ is measured based on the environmental performance index (EPI). Nath, Roberts and Madhoo. (2010) stated that Yale University and Columbia University had conducted research in 2006 and determined the EPI used to include dimensions of reducing environmental stress on human health, enhancing ecosystem vitality, and sound management of natural resource use (Aniela, 2019). Environmental accounting variable $\left(\mathrm{X}_{2} \mathrm{AK}\right)$ is measured by the amount of use of environmental costs (Sela, Karamoy, \& Mawikere, 2019; Yuliantini, Purnamawati, \& Herawati, 2017). According to Yuliantini et. all (2017), an accounting in which identification, measurement and allocation of environmental costs is environmental accounting and the costs are integrated in business decision making, and communicated to stakeholders (Yuliantini et al., 2017). The agency cost (ZAC) mediation variable is measured by the amount of costs incurred by the PDAM company to the board of directors as executor. Jensen and Meckling (1976) state that the owner of a company that spends a number of costs to supervise managers is the agency cost (Chamidah \& Asandimitra, 2017). The control variables in this study consisted of Size $\left(\mathrm{X}_{3} S\right)$, Coverage Service $\left(\mathrm{X}_{4} \mathrm{CS}\right)$, Non Revenue Water $(\mathrm{NRW})\left(\mathrm{X}_{5} \mathrm{NRW}\right)$ and Employe Ratio $\left(\mathrm{X}_{6} \mathrm{ER}\right)$.

Research methods are the methods used in research or the methods used by researchers to carry out research operations (Kothari, 2004). Testing the models and hypotheses in this study using multiple linear regression equations. Multiple linear regression is used to test the effect of two or more independent variables on one dependent variable. The regression equation used in the study is as follows:

Model 1

$\mathrm{YKKP}=\alpha_{1}+\beta_{1} \mathrm{X}_{1} \mathrm{KL}+\beta_{2} \mathrm{X}_{2} \mathrm{AK}+\beta_{3} \mathrm{X}_{3} \mathrm{~S}+\beta_{4} \mathrm{X}_{4} \mathrm{CS}+\beta_{5} \mathrm{X}_{5} \mathrm{NRW}+\beta_{6} \mathrm{X}_{6} \mathrm{ER}+\varepsilon$

Model 2

$\mathrm{YKKP}=\alpha_{2}+\beta_{1} \mathrm{X}_{1} \mathrm{KL}+\beta_{2} \mathrm{X}_{2} \mathrm{AK}+\beta_{3} \mathrm{ZAC}+\beta_{4} \mathrm{X}_{3} \mathrm{~S}+\beta_{5} \mathrm{X}_{4} \mathrm{CS}+\beta_{6} \mathrm{X}_{5} \mathrm{NRW}+\beta_{7} \mathrm{X}_{6} \mathrm{ER}+\varepsilon \ldots$

where $\mathrm{YKKP}$ is financial performance, $\mathrm{X}_{1} \mathrm{KL}$ is environmental performance, $\mathrm{X}_{2} \mathrm{AK}$ is environmental accounting, ZAC is agency cost, $\mathrm{X}_{3} \mathrm{~S}$ is Size, $\mathrm{X}_{4} \mathrm{CS}$ is Coverage Service, $\mathrm{X}_{5} \mathrm{NRW}$ is Non Revenue Water (NRW), $\mathrm{X}_{6} \mathrm{ER}$ is Employe Ratio, $\alpha$ is linear regression constant, $\beta_{\mathrm{n}}$ is the variable coefficient, and $\varepsilon$ is error.

Hypothesis testing is performed using statistical package software for the social sciences (SPSS) with descriptive statistical analysis testing and hypothesis testing consisting of the Significant Individual Parameter Test (t Test), and Simultaneous Significant Test (F Test). 
European Journal of Business and Innovation Research

Vol.8, No.5, pp 38-55, August 2020

Published by $\boldsymbol{E C R T D}-\boldsymbol{U K}$

Print ISSN: 2053-4019(Print), Online ISSN: 2053-4027(Online)

\section{RESULT}

\section{Sample Description}

The sample used in this study was taken by purposive sampling method, where the sample is selected based on certain criteria. The criteria of the sample chosen are the PDAMs in this study are as follows.

1. Registered at BPPSPAM in 2017.

2. Classified at small, medium and large scale companies.

3. Healthy categorized.

4. Located in regions I to IV in Indonesia.

5. Publish Financial Statements and Performance Reports in a row in the period 31 December 2016 to 31 December 2017.

6. Data on Subscription Relations Fees / Environmental Costs, Supervisory Board Fees / Audit fees / Complete 2016 Interest Interest Loans.

Based on the criteria mentioned above, obtained a sample of companies that can be used for research as many as 37 companies.

\section{Descriptive analysis test results}

Descriptive statistical analysis is performed to provide a description or description of the data. Descriptive analysis used in this study includes the average value (mean), standard deviation, maximum value, and minimum. In this study, descriptive statistics were processed using IBM SPSS Statistics 22. Descriptive statistical test results are shown in table 1.

Table 1. Descriptive statistical

\begin{tabular}{llllll}
\hline & N & Maximum & Minimum & Mean & Std. Deviation \\
\hline KinKeuPer (YKKP) & 37 & 0,600 & 0,003 &, 092 &, 123 \\
KinLing $\left(\mathrm{X}_{1}\right.$ KL) & 37 & 143 & 3,167 & 52,907 & 31,991 \\
AktLing $\left(\mathrm{X}_{2} \mathrm{AK}\right)$ & 37 & 0,032 & 0,000 & 0,003 & 0,006 \\
AgCos $(\mathrm{ZAC})$ & 37 & 0,004 & 0,000 & 0,002 & 0,001 \\
Size $\left(\mathrm{X}_{3} \mathrm{~S}\right)$ & 37 & 3 & 1 & 2,27 & 0,732 \\
CovServ $\left(\mathrm{X}_{4} \mathrm{CS}\right)$ & 37 & 1 & 0,163 & 0,548 & 0,259 \\
NewRevWat $\left(\mathrm{X}_{5} \mathrm{NRW}\right)$ & 37 & 0,472 & 0,138 & 0,298 & 0,075 \\
EmplRat $\left(\mathrm{X}_{6}\right.$ ER) & 37 & 8,5 & 1 & 4,658 & 1,886
\end{tabular}

NOTE: KinKeuPer: Corporate Financial Performance, KinLing; Environmental Performance, Akt Ling; Environmental Accounting, AgCos ; Agency Cost, Size; Company size by number of customers, CovServ; Coverage Service, NewRevWat; Non Revenue Water, EmplRat; Employe Ratio.

Table 1 shows the company's financial performance (YKKP) maximum value is 0.6 , the minimum is 0.003 , the average is 0.092 and the standard deviation is 0.123 . For environmental performance $(\mathrm{X} 1 \mathrm{KL})$, the maximum value is 143 , the minimum is 3.167 , the average is 52.907 , and the standard deviation is 31.991. In environmental accounting (X2AK), the maximum value is 0.032 , the minimum is 0.00 , the average is 0.003 , and the standard deviation is 0.006 . For agency cost (ZAC), the maximum value is 0.004 , the minimum is 0.00 , the average is 0.002 , and the standard deviation is 0.001 . For the control variable, Size (X3S) has a maximum value of 3 , a minimum of 1 , an average value of 2.27 , and a standard deviation of 0.732 . For 
Coverage Service (X4CS), the maximum value is 1 , the minimum is 0.163 , the average is 0.548 , and the standard deviation is 0.259 . In addition, Non Revenue Water (X5NRW) gets a maximum value of 0.472 , a minimum of 0.138 , an average of 0.298 , and a standard deviation of 0.075 . Finally on the Employee Ratio (X6ER) variable, the maximum value is 8.5 , the minimum is 1 , the average is 4.658 , and the standard deviation is 1.886 .

\section{Hypothesis test results}

The effect of environmental performance and environmental accounting on the financial performance of PDAMs was tested by linear regression analysis of model 1 and the results are shown in table 2.

Table 2. Model 1 Linear Regression Analysis Test Results

\begin{tabular}{|c|c|c|c|c|c|}
\hline Variabel & $\begin{array}{l}\text { Unstan } \\
\text { Coeffic }\end{array}$ & ized & $\begin{array}{l}\text { Standardized } \\
\text { Coefficients }\end{array}$ & $\mathrm{t}$ & Sig. \\
\hline (Constant) & $\begin{array}{l}\mathrm{B} \\
-5,157\end{array}$ & $\begin{array}{l}\text { Std. Error } \\
, 767\end{array}$ & Beta & $-6,728$ &, 000 \\
\hline KinLing (X1KL) &,- 035 &, 119 &,- 038 &,- 295 &, 770 \\
\hline AktLing (X2AK) & ,006 &, 070 &, 013 &, 082 & ,935 \\
\hline Size (X3S) & $-1,375$ &, 234 &,- 842 & $-5,868$ &, 000 \\
\hline CovServ (X4CS) &,- 134 &, 180 &,- 106 &,- 730 &, 471 \\
\hline NewRevWat (X5NRW &, 068 & ,399 &, 026 &, 165 &, 870 \\
\hline EmplRat (X6ER) &,- 212 &, 234 &,- 162 &,- 897 &, 377 \\
\hline \multicolumn{6}{|c|}{ a. Dependent Variable: Kinerja Keuangan } \\
\hline \multicolumn{6}{|c|}{0.796} \\
\hline $\operatorname{Adj} R$ & \multicolumn{5}{|c|}{0.561} \\
\hline F-Statisti & \multicolumn{5}{|c|}{8,662} \\
\hline Durbit Watson & \multicolumn{5}{|c|}{2,687} \\
\hline
\end{tabular}

NOTE: KinLing; Kinerja Lingkungan, Akt Ling; Akuntansi Lingkungan, Size; Ukuran Perusahaan dari jumlah pelanggan, CovServ; Coverage Service, NewRevWat; Non Revenue Water, EmplRat; Employee Ratio.

Table 2 shows that the influence of environmental performance variables on the financial performance of PDAMs has a regression coefficient of $-0.035, t_{\text {count }}$ of -0.295 and a significance value of 0.77 . The influence of environmental accounting variables on PDAM financial performance has a regression coefficient of $-0.006, \mathrm{t}_{\text {count }}$ of 0.082 and a significance value of 0.935 . The results of testing the effect of environmental performance, environmental accounting on PDAM financial performance mediated by agency cost in model 2 linear regression analysis are shown in table 3. 
European Journal of Business and Innovation Research

Vol.8, No.5, pp 38-55, August 2020

Published by $\boldsymbol{E C R T D}-\boldsymbol{U K}$

Print ISSN: 2053-4019(Print), Online ISSN: 2053-4027(Online)

Table 3. Model 2 Linear Regression Analysis Test Results

\begin{tabular}{|c|c|c|c|c|c|c|}
\hline \multicolumn{7}{|l|}{ Coefficients $^{\mathrm{a}}$} \\
\hline \multirow{2}{*}{\multicolumn{2}{|c|}{ Variabel }} & \multicolumn{2}{|c|}{$\begin{array}{l}\text { Unstandardized } \\
\text { Coefficients }\end{array}$} & \multirow{3}{*}{$\begin{array}{l}\text { Standardized } \\
\text { Coefficients } \\
\text { Beta }\end{array}$} & \multirow[t]{2}{*}{$\mathrm{t}$} & \multirow[t]{2}{*}{ Sig. } \\
\hline & & B & Std. Error & & & \\
\hline \multicolumn{2}{|l|}{ (Constant) } &,- 582 &, 525 & & $-1,109$ & ,277 \\
\hline \multicolumn{2}{|c|}{ KinLing (X1KL) } & 1,022 &, 051 &, 570 & 19,879 &, 000 \\
\hline \multicolumn{2}{|c|}{ AktLing (X2AK) } &, 971 &, 030 & 1,098 & 31,887 &, 000 \\
\hline \multicolumn{2}{|l|}{$\mathrm{AgCos}(\mathrm{ZAC})$} &,- 228 &, 081 &,- 118 & $-2,874$ & ,008 \\
\hline \multicolumn{2}{|l|}{ Size $(X 3 S)$} &,- 388 &, 150 &,- 124 & $-2,608$ & ,014 \\
\hline \multicolumn{2}{|c|}{ CovServ (X4CS) } &,- 034 & ,082 &,- 015 &,- 404 & ,692 \\
\hline \multicolumn{2}{|c|}{ NewRevWat (X5NRW) } &, 324 &, 177 & ,066 & 1,876 & 071 \\
\hline \multicolumn{2}{|c|}{ EmplRat (X6ER) } &,- 356 & ,102 &,- 139 & $-3,482$ & ,002 \\
\hline \multicolumn{7}{|c|}{ a. Dependent Variable: ROE } \\
\hline $\mathrm{R}$ & 0.992 & & & & & \\
\hline Adj R & 0.979 & & & & & \\
\hline F-Statisti & 235,055 & & & & & \\
\hline Durbit Watson & 1,856 & & & & & \\
\hline
\end{tabular}

NOTE: KinLing; Environmental Performance, Akt Ling; Environmental Accounting, AgCos ; Agency Cost, Size; Company size by number of customers, CovServ; Coverage Service, NewRevWat; Non Revenue Water, EmplRat; Employe Ratio.

Table 3 shows that the effect of environmental performance variables on PDAM financial performance mediated by agency cost has a regression coefficient of 1.022 , $\mathrm{t}_{\text {count }}$ of 19.879 and a significance value of 0,000 . The influence of environmental accounting variables on PDAM financial performance mediated by agency cost has a regression coefficient of $0.971, t_{\text {count }}$ of 31.887 and a significance value of 0.000 . The effect of agency cost variables on PDAM financial performance has a regression coefficient of $-0.227, \mathrm{t}_{\text {count }}$ of -2.787 and a significance value of 0.008 .

\section{DISCUSSION}

Descriptive statistics testing is used to statistically explain a data that refers to the minimum, maximum, average (mean), and standard deviation of all variables used in the study (Mulyana, 2017). Calculations that reflect the average of the mean deviations are standard deviations. The magnitude of the standard deviation illustrates the amount of variation in the data where if the average value < of the standard deviation values, then the average value generated on the variable is bad from the data obtained and it would be better if the average value $>$ of the standard deviation (Mulyana, 2017). The results of the descriptive statistical analysis test show that the average value of the financial performance and environmental accounting variables < of the standard deviation values. This shows the data obtained on the financial performance and environmental accounting variables from there are very large data deviations so that the spread of the data shows abnormal and biased results. Whereas in other variables the average value $>$ of the standard deviation values, the spread of the data is not biased or normal.

Model 1 linear regression test results show that PDAM financial performance is negatively affected by environmental performance and has no significant effect. Therefore, the first hypothesis related to environmental performance affecting financial performance is positively 
European Journal of Business and Innovation Research

Vol.8, No.5, pp 38-55, August 2020

Published by ECRTD-UK

Print ISSN: 2053-4019(Print), Online ISSN: 2053-4027(Online)

rejected. Likewise, financial accounting variables in which the company's financial performance is positively influenced by environmental accounting but has no significant effect. Because of this, the second hypothesis related to environmental accounting positively influences financial performance. The environmental performance carried out by the PDAM is likely to require a large enough cost so that the financial performance that occurs in the PDAM decreases therefore environmental performance negatively affects financial performance and this result is different from the tests conducted by Betts et. all. (2018), Chege and Wang (2019), and Martinez et. all. (2020) where in the study environmental performance affects company performance and financial performance positively (Betts et al., 2018; Chege \& Wang, 2019; Martinez et al., 2020). In contrast to environmental accounting where in this study the financial performance of PDAM companies is positively influenced by environmental accounting. This is because environmental accounting can optimize the use of finance for environmental management so that the use of environmental costs can be optimized and efficient even though it has no significant effect. This is consistent with previous research conducted by Qodriana (2017), Dewata et. all. (2018), Ratulangi et. all. (2018), Wang et. all. (2019), and Usman et. all. (2020) where environmental accounting performance positively influences company finances (Dewata et al., 2018; Qodriana, 2017; Ratulangi et al., 2018; Usman et al., 2020; M. X. Wang et al., 2019).

Model 2 linear regression test results show that agency cost negatively affects financial performance and has a significant effect. Because agency cost has a negative effect, the third hypothesis related to agency cost positively influences the company's financial performance. In addition, agency costs which mediate environmental performance have a positive and significant effect on financial performance. Thus, the fourth hypothesis related to agency cost mediation on environmental performance positively influences financial performance. This also applies to environmental accounting where the gency cost that mediates environmental accounting has a positive and significant influence on financial performance. Because of that, the fifth hypothesis related to agency cost mediation on environmental accounting positively affects financial performance. For PDAMs, agency costs incurred to pay the board of directors cause a decrease in PDAM's financial performance. The greater the value of agency costs incurred, the more declining its financial performance is likely due to the costs incurred large enough to burden the financial performance of the PDAM. This is not in accordance with research conducted by Layyinaturrobaniyah et. all. (2014), Cartinez et.all (2019), and Varela (2017) where agency costs can improve corporate financial performance (Canitez et al., 2019; Layyinaturrobaniyah et al., 2014; Varela, 2017) and these results are also in accordance with research conducted by Muclas and Alamsyah (2017) where agency cost has not consistently influenced financial performance, whereas in this study financial performance has decreased (Muchlas \& Alamsyah, 2017). Regarding the environmental performance carried out by the PDAM, with the existence of agency cost, the environmental performance has turned negative to positive. This is made possible by the board of directors who get high agency costs so that this will cause environmental performance to be carried out as optimal as possible so that financial performance increases. Likewise with environmental accounting, PDAMs that provide high agency costs cause an increase in the positive influence of environmental accounting where this causes the use of finance for environmental management to be carried out as optimal as possible and with the most efficient calculation possible. These results are consistent with research conducted by Layyinaturrobaniyah et. all. (2014), Cartinez et.all 
European Journal of Business and Innovation Research

Vol.8, No.5, pp 38-55, August 2020

Published by ECRTD-UK

Print ISSN: 2053-4019(Print), Online ISSN: 2053-4027(Online)

(2019), and Varela (2017) where agency costs can improve corporate financial performance (Canitez et al., 2019; Layyinaturrobaniyah et al., 2014; Varela, 2017).

\section{CONCLUSION}

The study related to PDAM financial performance shows that PDAM financial performance is directly affected negatively by environmental performance and directly positive by environmental accounting. This shows that the PDAM has to pay a large amount of cost in carrying out environmental performance so that the PDAM's financial performance decreases, whereas with the existence of environmental accounting, the PDAM can calculate the expenditure needed in environmental management so that the company's financial use for the PDAM can be more effective and efficient. agency cost mediates the implementation of environmental performance. This is different if the agency cost provided by the owner of the PDAM company mediates the implementation of environmental performance where the agency cost changes the negative influence of the environmental performance to be positive on the financial performance of the PDAM. Meanwhile, agency cost which mediates environmental accounting has a positive influence on the PDAM's financial performance and makes environmental accounting a significant effect on the PDAM company's financial performance. However, the agency cost itself has a negative and significant effect on the PDAM's financial performance. PDAMs that provide high agency cost to the board of directors of PDAM make the performance of the board of directors pay more attention and are responsible for environmental management so that the expenditure for such management is really carried out optimally and efficiently. Therefore, the amount of costs incurred by the local government as PDAM owner has a positive influence on the manager's performance which also has an impact on the environmental management and financial performance of the PDAM.

\section{REFERENCES}

Adib, M. S. (2016). Pengaruh Struktur Modal Dan Kepemilikan Saham Manajerial Terhadap Kinerja Perusahaan Dengan Agency Cost Sebagai Variabel Interventing (Studi Kasus Pada perusahaan Otomotif Yang Terdaftar Di Bursa Efek Indonesia). JAB, 2(1), 79-93.

Al-ahdal, W. M., Alsamhi, M. H., Tabash, M. I., \& Farhan, N. H. S. (2020). The impact of corporate governance on financial performance of Indian and GCC listed firms: An empirical investigation. Research in International Business and Finance, 51(August 2019), 101083. https://doi.org/10.1016/j.ribaf.2019.101083

Amerieska, S., \& Nurhidayah. (2014). Analisis Faktor - Faktor Yang mempengaruhi Kinerja Kemitraan Bisnis PT PLN (Studi Kasus Pada Kemitraan PT. PLN dengan AKLI Wilayah Kota Malang). Jurnal Manajemen Dan Akuntansi, 1(April), 1-12.

Aniela, Y. (2019). Peran Akuntansi Lingkungan Dalam Meningkatkan Kinerja Lingkungan Dan Kinerja Keuangan Perusahaan. Journal of Chemical Information and Modeling, 53(9), 1689-1699. https://doi.org/10.1017/CBO9781107415324.004

Baah, C., Jin, Z., \& Tang, L. (2020). Organizational and regulatory stakeholder pressures friends or foes to green logistics practices and financial performance: Investigating corporate reputation as a missing link. Journal of Cleaner Production, 247, 119125. https://doi.org/10.1016/j.jclepro.2019.119125

Barrow, C. J. (2006). Environmental management for sustainable development: Second edition. In Environmental Management for Sustainable Development: Second Edition. 
European Journal of Business and Innovation Research

Vol.8, No.5, pp 38-55, August 2020

Published by $\boldsymbol{E C R T D}-\boldsymbol{U K}$

Print ISSN: 2053-4019(Print), Online ISSN: 2053-4027(Online)

https://doi.org/10.4324/9780203016671

Betts, T. K., Super, J. F., \& North, J. (2018). Exploring the influence of institutional pressures and production capability on the environmental practices - Environmental performance relationship in advanced and developing economies. Journal of Cleaner Production, 187, 1082-1093. https://doi.org/10.1016/j.jclepro.2018.03.186

Brown, R. S. (2016). Lobbying, Political connectedness and financial performance in the air transportation industry. Journal of Air Transport Management, 54, 61-69. https://doi.org/10.1016/j.jairtraman.2016.03.009

Canitez, F., Alpkokin, P., \& Black, J. A. (2019). Agency costs in public transport systems: Netcost contracting between the transport authority and private operators - impact on passengers. Cities, 86(July), 154-166. https://doi.org/10.1016/j.cities.2018.09.010

Chamidah, N., \& Asandimitra, N. (2017). The determinant of agency cost in Indonesia. International Journal of Economic Research, 14(4), 83-97.

Chege, S. M., \& Wang, D. (2019). The influence of technology innovation on SME performance through environmental sustainability practices in Kenya. Technology in Society, 60(September 2019), 101210. https://doi.org/10.1016/j.techsoc.2019.101210

Crowther, D., \& Aras, G. (2008). Corporate Social Responsibility. In The Oxford Handbook of International Investment Law. https://doi.org/10.1093/oxfordhb/9780199231386.013.0017

Destia, P. damayanti. (2013). "Global Warming" in the Perspective of Environmental Management Accounting (EMA). Ilmiah ESAI, 7(1), 1-14.

Dewata, E., Jauhari, H., Sari, Y., \& Jumarni, E. (2018). Pengaruh Biaya Lingkungan, Kepemilikan Asing Dan Political Cost Terhadap Kinerja Perusahaan Pertambangan Di Indonesia. Jurnal AKSI (Akuntansi Dan Sistem Informasi), 3(2), 122-132. https://doi.org/10.32486/aksi.v2i2.271

Esteban-Sanchez, P., de la Cuesta-Gonzalez, M., \& Paredes-Gazquez, J. D. (2017). Corporate social performance and its relation with corporate financial performance: International evidence in the banking industry. Journal of Cleaner Production, 162, 1102-1110. https://doi.org/10.1016/j.jclepro.2017.06.127

Etriya, E., Scholten, V. E., Wubben, E. F. M., \& Omta, S. W. F. (Onno. (2019). The impact of networks on the innovative and financial performance of more entrepreneurial versus less entrepreneurial farmers in West Java, Indonesia. NJAS - Wageningen Journal of Life Sciences, 89(September), 100308. https://doi.org/10.1016/j.njas.2019.100308

Fitria, A., \& Wibowo, A. (2015). Model Penerapan Dan Pelaporan Biaya Lingkungan Sebagai Dasar Pengukuran Kinerja Lingkungan Pada Perusahaan Komersial. Prosiding Seminar Nasional FE UM Jember, 13-24.

Franco, S., Caroli, M. G., Cappa, F., \& Del Chiappa, G. (2019). Are you good enough? CSR, quality management and corporate financial performance in the hospitality industry. International Journal of Hospitality Management, (September), 102395. https://doi.org/10.1016/j.ijhm.2019.102395

Gan, H., Park, M. S., \& Suh, S. H. (2020). Non-financial performance measures, CEO compensation, and firms' future value. Journal of Business Research, 110(January), 213227. https://doi.org/10.1016/j.jbusres.2020.01.002

Haholongan, R. (2016). Kinerja Lingkungan dan Kinerja Ekonomi Perusahaan Manufaktur Go Public. Jurnal Ekonomi Dan Bisnis, 19(3), 413-423. https://doi.org/10.24914/jeb.v19i3.477 
European Journal of Business and Innovation Research

Vol.8, No.5, pp 38-55, August 2020

Published by $\boldsymbol{E C R T D}-\boldsymbol{U K}$

Print ISSN: 2053-4019(Print), Online ISSN: 2053-4027(Online)

Hansen, C., \& Block, J. (2020). Journal of Business Venturing Insights Exploring the relation between family involvement and fi $\mathrm{rms}$ ' fi nancial performance: A replication and extension meta-analysis. Journal of Business Venturing Insights, 13(September 2018), e00158. https://doi.org/10.1016/j.jbvi.2020.e00158

Indonesia, P. R. Undang-Undang No 32 Tahun 2004 Tentang Pemerintah Daerah. , (2004).

Indonesia, P. R. Undang - undang Republik Indonesia Nomor 7 Tahun 2004 Tentang Sumber Daya Air. , (2004).

Istiana, F. (2017). Kinerja Karyawan Perusahaan Daerah Air Minum ( PDAM ) Tirta Siak Dalam Penyediaan Kebutuhan Air Bersih Di Kota Pekanbaru. Jurusan Administrasi Publik Fakultas Ilmu Sosial Dan Ilmu Politik Universitas, 4(2), 1-15.

Jahmane, A., \& Gaies, B. (2020). Corporate social responsibility, financial instability and corporate financial performance: linear, non-linear and spillover effects - The case of the CAC 40 companies. Finance Research Letters, 101483. https://doi.org/10.1016/j.frl.2020.101483

Jefri, R. (2018). Teori Stewardship Dan Good Governance. Jurnal Riset Edisi XXVI, 4(3), 1428.

Kothari, C. R. (2004). Research Methodology Methods and Techniques (Second Revised Edition). In New Age International.

Kovermann, J., \& Velte, P. (2019). The impact of corporate governance on corporate tax avoidance-A literature review. Journal of International Accounting, Auditing and Taxation, 36, 100270. https://doi.org/10.1016/j.intaccaudtax.2019.100270

Layyinaturrobaniyah, Sudarsono, R., \& Fitriyana, D. (2014). Agency cost pada perusahaan keluarga dan non keluarga. Jurnal Siasat Bisnis, 18(2), 169-179. https://doi.org/10.20885/jsb.vol18.iss2.art3

Liu, Z. (2020). Unraveling the complex relationship between environmental and financial performance — A multilevel longitudinal analysis. International Journal of Production Economics, 219(October 2018), 328-340. https://doi.org/10.1016/j.ijpe.2019.07.005

Lu, L. W., \& Taylor, M. E. (2018). A study of the relationships among environmental performance, environmental disclosure, and financial performance. Asian Review of Accounting, 26(1), 107-130. https://doi.org/10.1108/ARA-01-2016-0010

Lucato, W. C., Costa, E. M., \& de Oliveira Neto, G. C. (2017). The environmental performance of SMEs in the Brazilian textile industry and the relationship with their financial performance. Journal of Environmental Management, 203, 550-556. https://doi.org/10.1016/j.jenvman.2017.06.028

Madison, K. J. (2014). Agency Theory and Stewardship Theory Integrated , Expanded , and Bounded by Context: An Empirical Investigation of Structure, Behavior, and Performance within Family Firms. https://doi.org/10.17129/botsci.8

Martinez, S., Alvarez, S., Capuano, A., \& Delgado, M. del M. (2020). Environmental performance of animal feed production from Camelina sativa (L.) Crantz: Influence of crop management practices under Mediterranean conditions. Agricultural Systems, 177(September 2019), 102717. https://doi.org/10.1016/j.agsy.2019.102717

Moon, H., \& Min, D. (2020). A DEA approach for evaluating the relationship between energy efficiency and financial performance for energy-intensive firms in Korea. Journal of Cleaner Production, 255, 120283. https://doi.org/10.1016/j.jclepro.2020.120283

Muchlas, Z., \& Alamsyah, A. R. (2017). Pengaruh Agency Cost Terhadap Kinerja Keuangan. Jibeka, 11(1), 92-98. 
European Journal of Business and Innovation Research

Vol.8, No.5, pp 38-55, August 2020

Published by $\boldsymbol{E C R T D}-\boldsymbol{U K}$

Print ISSN: 2053-4019(Print), Online ISSN: 2053-4027(Online)

Mulyana, A. (2017). PENGARUH BIAYA PRODUKSI DAN BIAYA PROMOSI TERHADAP LAB AUSAHA SAMSUNG Co TAHUN 2009-2015. Jurnal Manajemen Indonesia, 17(3), 185. https://doi.org/10.25124/jmi.v17i3.1155

Nazarian, A., Atkinson, P., \& Foroudi, P. (2017). Influence of national culture and balanced organizational culture on the hotel industry's performance. International Journal of Hospitality Management, 63, 22-32. https://doi.org/10.1016/j.ijhm.2017.01.003

Nurputri, B. A., \& Nuzula, N. F. (2019). Penerapan proper (program penilaian peringkat kinerja perusahaan dalam pengelolaanl lingkungan hidup) dalam kinerja lingkungan di PLTGU tanjung batu (studi pada pengendalian pencemaran air). Jurnal Administrasi Bisnis, 67(1), 25-34.

Petitjean, M. (2019). Eco-friendly policies and financial performance: Was the financial crisis a game changer for large US companies? Energy Economics, 80, 502-511. https://doi.org/10.1016/j.eneco.2019.01.028

Prakoso, B. I., Jonathan, L. C. A. R., \& Lau, E. A. (2013). Analisis Kinerja Perusahaan Daerah Air Minum ( Pdam ) Kabupaten Malinau Tahun 2013. Fakultas Ekonomi, 1-7.

Qian, W., Hörisch, J., \& Schaltegger, S. (2018). Environmental management accounting and its effects on carbon management and disclosure quality. Journal of Cleaner Production, 174, 1608-1619. https://doi.org/10.1016/j.jclepro.2017.11.092

Qodriana, E. L. (2017). Jurnal Accounting Environmental Application Study On Registed Company In BEI. Simki-Economic, 01(03), 15.

R, E. K., \& Hafifi, A. (2017). Kualitas Pelayanan Perusahaan Daerah Air Minum (PDAM) Kabupaten JEMBER. Jurnal Politico, 17(2), 361-390.

Ratulangi, A. V. J., Pangemanan, S., \& Tirayoh, V. (2018). Analisis Penerapan Akuntansi Lingkungan Terhadap Biaya Operasional Pengelolahan Limbah Pada Rumah Sakit Pancaran Kasih Manado. Going Concern: Jurnal Riset Akuntansi, 13(04), 410-418. https://doi.org/10.32400/gc.13.03.20292.2018

Rhou, Y., Singal, M., \& Koh, Y. (2016). CSR and financial performance: The role of CSR awareness in the restaurant industry. International Journal of Hospitality Management, 57, 30-39. https://doi.org/10.1016/j.ijhm.2016.05.007

Rodrigues, L., \& Rodrigues, L. (2018). Economic-financial performance of the Brazilian sugarcane energy industry: An empirical evaluation using financial ratio, cluster and discriminant analysis. Biomass and Bioenergy, 108(April 2017), 289-296. https://doi.org/10.1016/j.biombioe.2017.11.013

Rodriguez-Fernandez, M. (2016). Social responsibility and financial performance: The role of good corporate governance. BRQ Business Research Quarterly, 19(2), 137-151. https://doi.org/10.1016/j.brq.2015.08.001

Sela, A. Y., Karamoy, H., \& Mawikere, L. M. (2019). Analisis Penerapan Akuntansi Lingkungan pada RSUD DR. Sam Ratulangi Tondano. Indonesia Accounting Journal, 1(2), 57-62. https://doi.org/10.32400/iaj.26649

Shiu, Y. M. (2019). How does reinsurance and derivatives usage affect financial performance? Evidence from the UK non-life insurance industry. Economic Modelling. https://doi.org/10.1016/j.econmod.2019.09.048

Sianipar, W. A., \& Wahyono, H. (2018). Kinerja Pelayanan Publik Pdam Kabupaten Mempawah Berdasarkan Kepuasan Pelanggan. Jurnal Pembangunan Wilayah \& Kota, 14(3), 213. https://doi.org/10.14710/pwk.v14i3.17999

Singh, S. K., Giudice, M. Del, Chierici, R., \& Graziano, D. (2020). Green innovation and 
European Journal of Business and Innovation Research

Vol.8, No.5, pp 38-55, August 2020

Published by $\boldsymbol{E C R T D}-\boldsymbol{U K}$

Print ISSN: 2053-4019(Print), Online ISSN: 2053-4027(Online)

environmental performance: The role of green transformational leadership and green human resource management. Technological Forecasting and Social Change, 150(May 2019), 119762. https://doi.org/10.1016/j.techfore.2019.119762

Sofia, I. P. (2019). The Role of Corporate Diversification, Capital Structure Determinant, And Structure of Ownership on Earning Management with Information Asymmetry as Moderating Variable. Research Journal of Finance and Accounting, 10(14), 45-51. https://doi.org/10.7176/rjfa/10-14-05

Sumantri, B., \& Parwiyanto, H. (2017). Kualitas Pelayanan Perusahan Daerah Air Minum (PDAM) Kabupaten Sragen. Jurnal Wacana Publik, 1(1), 11-24. https://doi.org/10.1017/CBO9781107415324.004

Suseno, N. V., \& Widyastuti, M. (2014). Analisis Kualitas Air PDAM Tirta Manggar Kota Balikpapan. (492), 1-8.

Tahu, G. P. (2019). Pengaruh Kinerja Lingkungan dan Pengungkapan Lingkungan terhadap Profitabilitas Perusahaan (Studi Empiris Pada Perusahaan Pertambangan yang Terdaftar di BEI Tahun 2015-2017). JASa (Jurnal Akuntansi, Audit Dan Sistem Informasi Akuntansi), 14(1), 31-40.

Teodosiu, C., Gilca, A. F., Barjoveanu, G., \& Fiore, S. (2018). Emerging pollutants removal through advanced drinking water treatment: A review on processes and environmental performances assessment. Journal of Cleaner Production, 197, 1210-1221. https://doi.org/10.1016/j.jclepro.2018.06.247

Theodoulidis, B., Diaz, D., Crotto, F., \& Rancati, E. (2017). Exploring corporate social responsibility and financial performance through stakeholder theory in the tourism $\begin{array}{llll}\text { industries. } & \text { Tourism } & \text { Management, } & 62,\end{array}$ https://doi.org/10.1016/j.tourman.2017.03.018

Tzouvanas, P., Kizys, R., Chatziantoniou, I., \& Sagitova, R. (2019). Environmental and financial performance in the European manufacturing sector: An analysis of extreme tail $\begin{array}{llll}\text { dependency. British Accounting } & \end{array}$ https://doi.org/10.1016/j.bar.2019.100863

Ukko, J., Nasiri, M., Saunila, M., \& Rantala, T. (2019). Sustainability strategy as a moderator in the relationship between digital business strategy and financial performance. Journal of Cleaner Production, 236, 117626. https://doi.org/10.1016/j.jclepro.2019.117626

Usman, O., Alola, A. A., \& Sarkodie, S. A. (2020). Assessment of the role of renewable energy consumption and trade policy on environmental degradation using innovation accounting: Evidence from the US. Renewable Energy, 150, 266-277. https://doi.org/10.1016/j.renene.2019.12.151

Utama, A. A. G. S. (2016). Akuntansi Lingkungan Sebagai Suatu Sistem Informasi: Studi Pada Perusahaan Gas Negara (PGN). Esensi, 6(1), 89-100. https://doi.org/10.15408/ess.v6i1.3123

Varela, O. (2017). "Agency costs" when agents perform better than owners. Finance Research Letters, 23, 103-113. https://doi.org/10.1016/j.frl.2017.07.019

Walls, J. L., Berrone, P., \& Phan, P. H. (2012). Corporate Governance And Enviromental Performance: Is There Really A Link? Startegic Management Journal, (November 2007), 1-22. https://doi.org/10.1002/smj

Wang, H., Lu, W., Ye, M., Chau, K. W., \& Zhang, X. (2016). The curvilinear relationship between corporate social performance and corporate financial performance: Evidence from the international construction industry. Journal of Cleaner Production, 137, 1313- 
1322. https://doi.org/10.1016/j.jclepro.2016.07.184

Wang, M. X., Liang, L. N., Siu, W. S., Fan, D., Sun, H. R., Zhao, H. H., .. Wu, W. J. (2019). Loss accounting of environmental pollution within Pearl River Delta region, South China. Environmental Pollution, 249, 676-685. https://doi.org/10.1016/j.envpol.2019.03.081

Wang, S., Wang, H., Wang, J., \& Yang, F. (2020). Does environmental information disclosure contribute to improve firm financial performance? An examination of the underlying mechanism. Science of the Total Environment, 714(96), 136855. https://doi.org/10.1016/j.scitotenv.2020.136855

Winarno, S. H. (2017). Penilaian Kinerja Keuangan Perusahaan Melalui Analisis Rasio Profitabilitas. Jurnal Ilmiah Akuntansi Dan Bisnis, IV(2), 45-51.

Yuliantini, P. A., Purnamawati, I. G. A., \& Herawati, N. T. (2017). ANALISIS PENERAPAN AKUNTANSI LINGKUNGAN PADA UNIT MILIK DESA ( Studi Kasus Pada BUM Desa Mandala Giri Amertha Desa Tajun, Kecamatan Kubutambahan, Kabupaten Buleleng, Provinsi Bali). E-Journal S1 Ak Universitas Pendidikan Ganesha, 7(1), 1-12. 